\title{
Editorial
}

\begin{tabular}{c} 
CHRIS HEALY \\
UNIVERSITY OF MELBOURNE \\
AND \\
KATRINA SCHLUNKE \\
UNIVERSITY OF TECHNOLOGY, SYDNEY \\
\hline
\end{tabular}

The organising title of this issue of Cultural Studies Review-Interventions-recalled for us something said by Grant Farred in his essay 'Out of Context', which appeared in The Renewal of Cultural Studies edited by Paul Smith: 'Because the history of cultural studies is-and has been since its founding in the ideological, intellectual, and ethical crises of the mid-1950s-the history of intervention into the particularities of successive political moments, cultural studies is perforce the discipline of necessary, which is to say generative, insufficiency.' ${ }^{1}$ Farred's paradoxical formulation, in which 'intervention' might seem to provide the fuel to run the engine that is cultural studies, insists nevertheless that because each moment of intervention is particular, cultural studies efforts will be politically, methodologically or theoretically insufficient, perhaps always willing but never quite able. But Farred's point is that the drive to intervene and the insufficiency of

\section{ISSN 1837-8692}

Cultural Studies Review 2015. @ 2015 Chris Healy and Katrina Schlunke. This is an Open Access article distributed under the terms of the Creative Commons Attribution 4.0 Unported (CC BY 4.0) License (https://creativecommons.org/licenses/by/4.0/), allowing third parties to copy and redistribute the material in any medium or format and to remix, transform, and build upon the material for any purpose, even commercially, provided the original work is properly cited and states its license. 
'old' methods as responses to new political sites and institutional eruptions has meant that cultural studies has in a very distinctive sense been forced to invent new methods, to cobble together existing methods, to engage contingently with emerging cultures. 'Interventions' call on cultural studies to look elsewhere, in what Farred calls 'the imperative to think out of context'.

The research essays in this volume do just that. Eve Vincent's ethnographic work in the desert town of Ceduna and its localised museum was partly driven by a desire to record the difference of its history. She writes: 'I did not want to narrate the past as "a chain of events", something agreed upon or stable.' Vincent's desire to open up the potentiality of the future seems, in a way, dragged down by the historical knowledge so defensively sandbagged in by the local museum and its white custodians. Catherine Noske has followed the work of Etienne Souriau through Australian thinkers such as Stephen Muecke, Paul Carter and Lyn McCredden to create a very exciting picture of a vital Australian cultural studies that recasts academic work and cultural studies thinking as a 'poetics of doing'. Thinking about 'intervention' through Noske we might need to consider whether 'real interventions' need to have connective, productive and life sustaining effects rather than 'merely' interpretive or argumentative judgements. Elsewhere in this volume Meera Atkinson writes of the articulations of trauma that occur, 'not in some linear, cause and effect, predictable fashion, but in a myriad, chaotic, continual and often imperceptible movement of circulating affect'. This gives rise to what she has termed 'cyclical haunting'. In that sense we might also need to ask: under what circumstances is 'connection' also 'life sustaining'? For Friedemann J. Weidauer the 'coming of age' films in America and Germany sustained an order of rebellion only to be resolved into large notions of societal order and maturity.

The title, 'Interventions', was also inspired by 'Same But Different', the special section edited by Jennifer Biddle and Lisa Stefanoff, which makes up the second half of this issue. The artworks, reports on exhibitions, interviews, essays and public addresses gathered together in the section were not an organised response to the Northern Territory Intervention (officially, the Northern Territory National Emergency Response Act 2007), rather they emerged from forums concerned with experimental and innovative Indigenous arts held in Alice Springs. But as the guest editors suggest, this collection 'can be understood as itself an intervention in the 
non-consultative and top-down tendencies of current national policy and debate.' Of course, the tendency of some readers in both Marrickville and Montreal might be to consider such contributions from, and about, very remote parts of Australia as of arcane interest only. On the contrary, we would suggest that, for any reader, this work is good to think with. 'Interventionist' thinking and philosophy makes connections through art and dance as well as essays. The 'interventionist' action in these contributions offer accounts of an art/land/community based politic that suggests connections between transnational scholarly worlds and some Australian desert communities that are rarely elsewhere.

A number of compelling reviews complete this edition. Brigid Rooney's review essay on NewSouth's Australian cities series explores with great finesse the ways in which modernity and the novel have moved through the urban to write tales of awkward togetherness. Sara Knox's work-a-day association with the unassimilable takes us on a tremulous path into the paranormal while we float and are drawn into the currents of Marama Muru-Lanning's engagement with the life of (mostly) Canadian waters. Eluned Summers-Bremner explores the history of dreams and Adam Gall carefully reminds us in his telling rejoinder to cosmopolitical thinking that: 'It is worth remembering that speaking in the name of the tacit, the local, the affective, is not the same as providing tools for thinking about those things.' David Herkt's figuration of The Nearness of Others is also a poetic evocation of this historical moment of HIV in the west where it is now the 'aftermath' that is being negotiated and 'tactfully' lived and Valerie Coom's consideration of miscegenation and intimacy suggests: 'how much Aboriginal people know and understand about white families, their tensions and secrets. While this knowledge refers to the broader categories of race, gender and colonisation, it also remains a deeply personal knowledge grounded in the lived experience of mixed-race intimacies.'

Perhaps this issue can evoke both a legacy of intervening that has given rise to new methods and new styles of thinking, and the necessity for this to be called forth again and again as the dynamism of contemporary culture relentlessly generates novel sites of intervention from the intimately subjective to the familiarly local and the intimidatingly global. Each part of this edition contributes in its own way to that very valuable past, performed here so adroitly in the present. 
-NOTES

1 Grant Farred, 'Out of Context: Thinking Cultural Studies Diasporically', in Paul Smith (ed.), The

Renewal of Cultural Studies, Temple University Press, Philadelphia, 2011, p. 160.

\section{-BIBLIOGRAPHY}

Farred, G., 'Out of Context: Thinking Cultural Studies Diasporically', in Smith, P. (ed.), The Renewal of Cultural Studies, Temple University Press, Philadelphia, 2011. 